\title{
SIMATIK : APLIKASI SIMULASI BANK SOAL TES POTENSI AKADEMIK (TPA) BERBASIS MULTI PLATFORM
}

\author{
Made Hendra Yudha Saputra ${ }^{1}$, I Ketut Resika Arthana ${ }^{2}$, Gede Saindra Santyadiputra ${ }^{3}$ \\ 1,2,3 Jurusan Pendidikan Teknik Informatika, Fakultas Teknik dan Kejuruan \\ Universitas Pendidikan Ganesha \\ Singaraja, Indonesia
}

e-mail: hendrayudha02@gmail.com,resika@undiksha.ac.id,gsaindras@undiksha.ac.id

\begin{abstract}
Penelitian ini bertujuan untuk: (1) menghasilkan rancang bangun dan implementasi Simatik : Aplikasi Simulasi Bank Soal Tes Potensi Akademik (TPA) Berbasis Multi Platform, (2) Mengetahui respon dari Pengguna terhadap Simatik : Aplikasi Simulasi Bank Soal Tes Potensi Akademik (TPA) Berbasis Multi Platform. Dalam perancangannya, aplikasi ini akan menggunakan arsitektur client-server untuk melakukan proses pertukaran data.

Perancangan dilakukan dengan menggunakan model fungsional berupa UML. Model fungsional berupa UML tersebut diimplementasikan dalam sebuah framework yaitu Phonegap dengan bahasa pemrograman HTML5. Untuk mengetahui respon terhadap Simatik : Aplikasi Simulasi Bank Soal Tes Potensi Akademik (TPA) Berbasis Multi Platform ini diperoleh dengan menggunakan metode angket.

Hasil akhirnya yaitu berupa Aplikasi Simatik berbasis Multi Platform yang dapat diinstall pada perangkat mobile untuk digunakan dalam latihan soal-soal yang terkait dengan Tes Potensi Akademik (TPA). Berdasarkan hasil uji usability, aplikasi Simatik berbasis Multi Platform ini mendapatkan persentase hasil sebesar 95,6 \% dengan kategori sangat baik yang berarti dalam pengoperasiannya aplikasi ini mudah untuk digunakan dan dapat berfungsi sesuai dengan fungsi seharusnya.
\end{abstract}

Kata kunci: Phonegap, Multi Platform, Mobile, Tes Potensi Akademik (TPA), Simatik

\begin{abstract}
This research is purpose to : (1) produce generate design and implementation Simatik : Aplikasi Simulasi Bank Soal Tes Potensi Akademik (TPA) Berbasis Multi Platform (2) To knowing the response of users to Simatik : Aplikasi Simulasi Bank Soal Tes Potensi Akademik (TPA) Berbasis Multi Platform. In its design, this application will use the clientserver architecture to make the exchange process of data.

The design were done by using a functional model UML form. The functional model UML form is implemented within a framework that is phonegap with HTML 5 programming languages. To determine the response of Simatik. Simatik: Aplikasi Simulasi Bank Soal Tes Potensi Akademik (TPA) Berbasis Multi Platform obtained by using questionnaries. Finally result is Simatik Application based on Multi Platform which can be installed on the mobile device for use in practice of TPA. Based on the results of usability test, this Simatik Aplications based on Multi Platform got 95,6\% with very good category, it means that the operationed of this application is easy to use and it can function as according to the its properly function.
\end{abstract}

Keywords : Phonegap, Multi Platform, Mobile, Tes Potensi Akademik (TPA), Simatik 


\section{PENDAHULUAN}

Tes Potensi Akademik atau TPA adalah sebuah tes yang bertujuan untuk mengetahui bakat dan kemampuan seseorang di bidang keilmuan atau akademis. TPA pada umumnya memiliki empat jenis soal yaitu tes verbal atau bahasa, tes numerik atau angka, tes logika, dan tes spasial atau gambar.

Saat ini, selain untuk menyeleksi calon mahasiswa di Perguruan Tinggi, TPA juga telah menjadi tes standar dalam seleksi penerimaan Calon Pegawai Negeri Sipil (CPNS) dan juga rekrutmen karyawan swasta serta karyawan BUMN. Berdasarkan hal itu, sekarang sudah banyak pihak yang menyediakan latihan atau simulasi TPA baik itu berupa buku-buku soal, website dan berupa aplikasi baik itu di komputer maupun perangkat bergerak berupa handphone atau mobile.

Simulasi merupakan suatu aktivitas yang menirukan operasi dan perilaku dari berbagai macam situasi nyata, baik fasilitas maupun prosesnya. Keadaan nyata yang akan disimulasikan itu dinamakan sistem, dimana untuk mempelajarinya diperlukan berbagai asumsi. Berdasarkan pengertian tersebut, simulasi Tes Potensi Akademik (TPA) dapat diartikan sebuah tiruan dari tes TPA yang sebenarnya baik itu dari segi fitur, cara menjawab, konten serta karakteristik dari tes itu sendiri tanpa mengesampingkan tujuan dari tes tersebut. Pada simulasi TPA biasanya selalu di sertai oleh pembahasan untuk memudahkan pengguna dalam memahami setiap soal sehingga apabila pada tes yang sebenarnya terdapat soal dengan karakteristik sama maka dapat dijawab dengan mudah.

Penulis mengadakan survey terhadap 55 orang responden berumur 18 tahun ke atas untuk mengetahui tingkat pemahaman masyarakat mengenai pembahasan soal pada latihan atau simulasi TPA. Dari hasil observasi tersebut diketahui bahwa sebagian besar responden mengaku kurang memahami pembahasan soal pada saat responden melakukan latihan soal TPA.

Dari survey di atas dapat dinyatakan bahwa media non elektronik sebagai wadah latihan atau simulasi TPA seperti dalam format buku-buku maupun lembar tes masih memiliki beberapa kekurangan. Sebagian besar responden mengeluhkan kurang lengkapnya pembahasan yang didapat serta banyak pembahasan yang sulit dimengerti. Kekurangan lain berdasarkan survey yang dilakukan adalah kurang praktisnya media non elektronik apabila digunakan sebagai wadah latihan atau simulasi TPA. Pemanfaatan teknologi Mobile dengan Multi Platform merupakan salah satu solusi untuk permasalahan tersebut. Multi Platform dipilih karena dalam implementasinya aplikasi akan dapat dijalankan di berbagai perangkat mobile dengan sistem operasi yang berbeda beda seperti iOS, Android dan Windows Phone. Hal ini semakin diperkuat dari hasil survey yang menyatakan bahwa sebanyak 53 dari 55 orang responden setuju jika latihan TPA ini dibuat menjadi sebuah aplikasi Multi Platform yang disertai pembahasan berupa video animasi untuk soal tes gambar. Dengan demikian tujuan dari pengembangan aplikasi yaitu ingin menjangkau seluruh kalangan pengguna mobile dapat terpenuhi.

Berdasarkan uraian di atas, akan dibangun sebuah aplikasi "Simatik : Simulasi Bank Soal Tes Potensi Akademik (TPA) Berbasis Multi Platform" berupa latihan atau simulasi yang memiliki tampilan menarik dan pembahasan dalam bentuk animasi video yang dapat memudahkan pengguna dalam memahami soal yang telah diberikan. Pada aplikasi ini nantinya berisi soal-soal terkait TPA seperti tes verbal atau bahasa, tes numerik atau angka, tes logika, dan tes spasial atau gambar yang di random sesuai dengan kebutuhan dan akan selalu diperbaharui pada saat pengguna menggunakan aplikasi dengan cara online ke internet.

Aplikasi ini ditujukan untuk calon mahasiswa yang ingin mencari Perguruan Tinggi Negeri, Calon Pegawai Negeri Sipil (CPNS), calon rekrutmen POLRI, calon rekrutmen tenaga dosen dan pengguna lain yang mengikuti tes masuk sejenis. Dengan adanya aplikasi ini, diharapkan dapat mengukur kemampuan akademik pengguna dan mampu memberikan sebuah kontribusi yang bermanfaat dan juga dapat membantu pengguna untuk mempermudah dalam belajar dan lebih menyingkat waktu belajar. 


\section{KAJIAN TEORI}

A. Tes Potensi Akademik (TPA)

Tes Potensi Akademik (TPA) adalah sebuah tes yang bertujuan untuk mengetahui bakat dan kemampuan seseorang di bidang keilmuan (akademis). Tes ini juga sering dihubungkan dengan kecerdasan seseorang.

B. Jenis Soal Tes Potensi Akademik (TPA) Jenis-jenis soal TPA ada empat yang meliputi tes verbal, tes kemampuan kuantitatif, tes penalaran atau logika dan tes gambar.

\section{Aplikasi Native, Hybrid dan Web}

Native Application adalah aplikasi yang terpasang atau ter-install pada perangkat mobile seperti Android, IOs, Windows Phone, Symbian, atau Blackberry yang memiliki kelebihan yaitu aplikasi berjalan lebih fleksibel dan lebih cepat. Sedangkan mobile web application (HTML5) adalah aplikasi berbasis website yang hanya dapat diakses melalui modern web browser yang sudah mendukung HTML5.

\section{Phonegap}

Phonegap adalah sebuah framework pembuatan aplikasi mobile berbasis open source. Phonegap framework memungkinkan seseorang mengembangkan aplikasi native mobile menggunakan keahlian HTML, CSS dan JavaScript. Sebuah aplikasi yang dibuat menggunakan framework Phonegap dapat di-deploy ke berbagai platform yaitu iOS, Android, Windows Mobile, Blackberry, WebOS, Symbian dan Bada.

\section{E. Android}

Android merupakan platform mobile terpopuler di dunia. Sistem Operasi ini telah digunakan ratusan juta orang di lebih dari 190 negara di seluruh dunia. Terdapat beberapa versi dari sistem operasi Android dari awal perkembangannya hingga sekarang.

\section{F. iOS}

iOS (sebelumnya iPhone OS) adalah sistem operasi perangkat bergerak yang dikembangkan dan didistribusikan oleh Apple Inc. Userinterface dari iOS menggunakan dasar konsep dari direct manipulation, menggunakan multi-touch gestures.

\section{METODE PENELITIAN}

Pengembangan aplikasi Simatik berbasis Multi Platform ini menggunakan metode pendekatan penelitian pengembangan (Research and Development). Metode penelitian ini dipilih karena prosedur yang ada di dalamnya sangat tepat untuk mengembangkan sebuah media pembelajaran atau latihan yang bertujuan untuk mengembangkan dan memvalidasi produk. Metode penelitian jenis ini merupakan metode penelitian yang digunakan untuk menghasilkan produk tertentu dan menguji keefektifan produk tersebut. Sedangkan pengembangan Aplikasi Simatik Berbasis Multi Platform ini menggunakan model ADDIE. Model ini dipilih karena lebih sederhana dan mudah dipelajari serta strukturnya yang sistematis akan membuat penerapan model penelitian ini menjadi lebih terarah. Maksud dari terarah di sini adalah bahwa model penelitian ini, pada evaluasi setiap fasenya dapat membawa pengembangan pembelajaran ke fase selanjutnya.

\section{A. Analisis Masalah dan Usulan Solusi \\ Dari hasil analisis tentang} permasalahan yang didapat setelah penulis menyebarkan angket dan observasi terhadap buku-buku dan aplikasi yang terkait dengan Tes Potensi Akademik (TPA), terdapat beberapa permasalahan yang terjadi di antaranya sebagai berikut.

(1) Pada beberapa media penyedia latihan soal Tes Potensi Akademik (TPA) hanya menyediakan latihan soal Tes Potensi Akademik (TPA) pada satu kategori keperluan tes saja. (2) Sebagian besar masyarakat belum memahami pembahasan soal pada latihan soal Tes Potensi Akademik (TPA). (3) Pembahasan soal Tes Potensi Akademik (TPA) pada media non elektronik (buku, lembar tes) kurang lengkap dan sulit dimengerti. (4) Pada pembahasan soal Tes Potensi Akademik (TPA) media non elektronik (buku, lembar tes) pembaca masih harus membuka lembaran satu persatu antara lembar soal dan pembahasan sehingga dapat memakan waktu yang cukup 
lama. (5) Pada pembahasan soal Tes Potensi Akademik (TPA) media non elektronik (buku, lembar tes) lebih didominasi oleh kata-kata sehingga memungkinkan kurangnya minat masyarakat terhadap latihan soal TPA, padahal latihan terhadap Tes Potensi Akademik (TPA) sangat penting sebagai persiapan menghadapi tes yang sesungguhnya. (6) Pada beberapa media elektronik (website, aplikasi, e-book) masih belum terdapat fitur seperti timer, random soal, penskoran langsung dan pembahasan yang interaktif.

Berdasarkan hasil analisis masalah di atas maka solusi yang dapat diusulkan adalah dikembangkannya Aplikasi Simatik berbasis Multi Platform yang nantinya dapat digunakan oleh pengguna yang ingin melakukan latihan soal-soal pada berbagai keperluan tes yang terkait dengan Tes Potensi Akademik (TPA). Perangkat lunak yang dikembangkan ini diharapkan dapat menangani permasalahan yang didapat.

\section{B. Analisis Perangkat Lunak}

1. Kebutuhan Perangkat Lunak

Kebutuhan fungsional perangkat lunak antara lain, (1) Peserta latihan dapat login ke aplikasi. (2) Peserta latihan dapat memilih kategori keperluan tes seperti tes CPNS, tes SBMPTN, tes POLRI, tes BUMN dan tes TKDA. (3) Peserta latihan dapat memilih paket soal. (4) Peserta latihan dapat menjawab soal berdasarkan kategori keperluan tes dan paket soal yang dipilih dengan timer sebagai acuan. (5) Peserta latihan dapat melihat skor akhir dari paket soal yang dijawab sebelumnya. (6) Peserta latihan dapat melihat kunci jawaban setelah menyelesaikan simulasi soal. (7) Peserta latihan dapat melihat analisis dari setiap tipe soal yang dijawab sehingga Peserta latihan dapat mengetahui tingkat kemampuan dan pemahaman pada masing-masing tipe soal. (8) Peserta latihan dapat melihat history paket soal yang sudah dijawab sebelumnya. (9) Peserta latihan dapat mengirim feedback terhadap masing-masing soal kepada Administrator. (10) Peserta latihan dapat melihat pembahasan berupa video animasi untuk soal visual atau gambar. (11) Peserta latihan dapat melihat nilai dari peserta latihan yang terdaftar ke sistem berdasarkan kategori keperluan yang dipilih untuk mengetahui perkembangan kemampuan peserta berupa papan nilai. (12) Admin dapat login ke aplikasi. (13) Admin dapat mengelola akun Operator. Admin dapat mengelola paket siap publish dan sudah publish. (14) Admin dapat mengelola akun Peserta. (15) Admin dapat mengelola kategori keperluan tes. (16) Admin dapat mengelola paket soal. (17) Admin dapat mengelola feedback soal. (18) Operator dapat login ke aplikasi. (19) Operator dapat mengelola paket belum publish dan siap publish. (20) Operator dapat mengelola bobot soal. (21) Operator dapat mengelola soal TPA. (22) Operator dapat mengelola feedback soal.

Kebutuhan Non Fungsional perangkat lunak antara lain, (1) Usability (2) Portability 3) Pengembangan aplikasi Simatik ini dibuat sebagai media belajar atau latihan yang bersifat multimedia interaktif.(4) Aplikasi dapat merespon pengguna dalam waktu 1-2 detik untuk pindah ke halaman sebelum atau pun berikutnya. Untuk halaman tertentu, aplikasi dapat merespon maksimal dalam waktu 8 detik.

2. Tujuan Perangkat Lunak

Adapun tujuan penelitian ini adalah dapat membantu peserta latihan soal dalam melakukan latihan soal terkait Tes Potensi Akademik (TPA), baik itu dalam hal penyediaan soal-soal secara random hingga penyediaan pembahasan soal.

3. Masukkan dan Keluaran Perangkat Lunak

Adapun yang menjadi masukan dari aplikasi Simatik adalah berupa data kategori keperluan tes, data tipe soal, data bobot, data paket, data soal dan data peserta latihan. Dari semua data tersebut akan diolah sehingga menghasilkan keluaran berupa data skor akhir, informasi jawaban benar dan informasi latihan yang dilakukan sebelumnya.

4. Model Fungsional

Pemodelan fungsional perangkat lunak menggunakan UML (Unified Modeling Language) yaitu use case diagram. Rancangan dapat dilihat seperti gambar 1.

C. Perancangan Perangkat Lunak

1. Perancangan Paket Soal

Rancangan paket soal merupakan desain jumlah paket soal yang akan 
digunakan pada aplikasi Simatik. Paket soal nantinya disesuaikan dengan jumlah kategori keperluan tes. Pada penelitian ini, terdapat batasan pada kategori keperluan tes yaitu hanya terdiri kategori keperluan tes CPNS, TKDA, SBMPTN, POLRI dan BUMN. Masing-masing dari kategori keperluan tes akan dikembangkan menjadi 2 paket soal dengan nama yang berbeda namun masih ada hubungannya dengan kategori keperluan tes. Seperti misalnya untuk kategori keperluan tes CPNS akan dikembangkan menjadi 2 paket soal dengan nama Paket CPNS 01 dan Paket CPNS 02 dengan tingkat kesulitan yang berbeda. Setiap paket soal akan memiliki variasi soal dan tingkat kesulitan soal yang berbeda dengan paket soal lainnya dalam satu kategori keperluan tes sesuai kebutuhan tergantung dari nilai akhir Peserta.

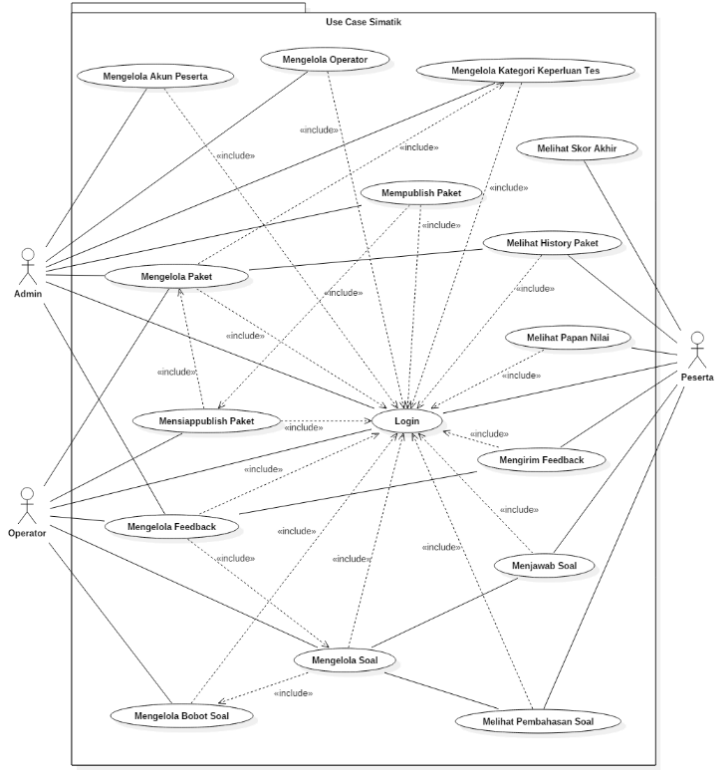

Gambar 1. Use Case Diagram Simatik

\section{Perancangan Soal dan timer}

Rancangan soal dan timer merupakan pemodelan mengenai jumlah soal dan batasan waktu dalam menjawab soal (timer) pada setiap paket soal yang akan digunakan pada aplikasi Simatik. Berdasarkan observasi terhadap aplikasi yang terkait dengan simulasi TPA, didapat bahwa setiap paket soal nantinya akan berisi 90 butir soal hasil random dari 4 tipe soal yaitu verbal, angka, logika dan gambar. Untuk menjawab 90 butir soal tersebut, Peserta akan diberi waktu 105 menit. Jadi apabila Peserta menjawab soal melebihi waktu yang diberikan, maka aplikasi akan langsung menuju halaman skor akhir dari paket yang dipilih Peserta. Jadi dapat diperoleh kesimpulan bahwa untuk menjawab 1 soal, Peserta diberi waktu maksimal yaitu

$$
\frac{90}{105}=0,857 \text { menit }
$$

\section{Perancangan Penilaian}

Rancangan penilaian merupakan pemodelan mengenai nilai atau skor yang diberikan kepada Peserta setelah menjawab 1 paket soal. Berdasarkan observasi terhadap aplikasi yang terkait dengan simulasi TPA, didapat bahwa setiap paket soal nantinya akan dinilai dengan kisaran nilai antara 0 sampai 100 . Jadi untuk nilai terendah adalah 0 dan nilai tertingginya adalah 100.

Untuk mendapatkan nilai tersebut, perancangan rumus yang diperoleh adalah sebagai berikut.

$$
\frac{\text { banyaknya jawaban benar }}{90} \boldsymbol{x} 100
$$

Jadi apabila Peserta menjawab benar sebanyak 70 maka dapat diperoleh nilai sebesar:

$$
\frac{70}{90} \times 100=77,7
$$

\section{Perancangan Struktur Data \\ Perangkat struktur data Aplikasi Simatik berbasis Multi Platform dirancang menggunakan basis data dan menggunakan 13 tabel yang berfungsi menyimpan data.}

\section{HASIL DAN PEMBAHASAN}

A. Implementasi Perangkat Lunak

1. Lingkungan Implementasi Perangkat Lunak

(a) Spesifikasi Perangkat Keras Aplikasi Simatik berbasis Multi Platform ini dikembangkan pada lingkungan perangkat keras komputer mobile (laptop) yang memiliki spesifikasi sebagai berikut.

- Monitor 14 inchi dengan resolusi $1366 \times 768$ pixel

- RAM dengan kapasitas 4 GB DDR3 dan media Penyimpanan Harddisk 500GB

- Processor Intel® Core i3 dengan CPU 2.30 Ghz 
(b) Spesifikasi Perangkat Lunak Aplikasi Simatik berbasis Multi Platform dikembangkan pada lingkungan perangkat lunak sebagai berikut.

- Phonegap Desktop v.0.3.3

- Phonegap Mobile.

- Adobe Phonegap Build

- Notepad ++ v 6.8.7

2. Implementasi Perangkat Lunak pada Perangkat Multi Platform

Implementasi perangkat lunak Aplikasi
Simatik Berbasis Multi Platform penulis lakukan dengan menggunakan Ripple Emulator Phonegap. Hal ini penulis lakukan karena masih minimnya perangkat Multi Platform yang akan digunakan untuk implementasi perangkat lunak Aplikasi Simatik. Untuk lebih lengkapnya implementasi perangkat lunak pada perangkat multi platform dijabarkan pada Tabel 1.

Tabel 1. Kategori Hasil Uji Ahli Isi Implementasi Perangkat lunak pada Perangkat Multi Platform

\begin{tabular}{|c|c|c|c|}
\hline & Nama Perangkat & Spesifikasi & Hasil \\
\hline 1. & $\begin{array}{l}\text { Blackberry Bold } \\
9900\end{array}$ & $\begin{array}{l}\text { - OS : Blackberry OS } 7 \\
\text { - Perangkat : Blackberry } \\
\text { - Layar : } 640 \text { x } 480\end{array}$ & Berhasil \\
\hline 2. & Blackberry Q10 & $\begin{array}{l}\text { - OS : Blackberry OS } \\
10.1 \\
\text { - Perangkat : Blackberry } \\
\text { - Layar : } 720 x 720\end{array}$ & Berhasil \\
\hline 3. & Palm Pre & $\begin{array}{l}\text { - OS : WebOS versi } 1 . x \\
\text { - Perangkat : Palm } \\
\text { - Layar : } 320 \text { x } 480\end{array}$ & Berhasil \\
\hline 4. & HP Pre 3 & $\begin{array}{l}\text { - OS : WebOS versi 2.x } \\
\text { - Perangkat : HP } \\
\text { - Layar : } 480 \text { x } 800\end{array}$ & Berhasil \\
\hline 5. & Nexus S & $\begin{array}{l}\text { - OS : Android v 2.3.x } \\
\text { - Perangkat : Samsung } \\
\text { - Layar : } 480 \text { x } 800\end{array}$ & Berhasil \\
\hline 6. & Nexus 4 & $\begin{array}{l}\text { - OS: Android v 4.2.x } \\
\text { - Perangkat : LG } \\
\text { - Layar : } 768 \times 1280\end{array}$ & Berhasil \\
\hline 7. & Nokia N8 & $\begin{array}{l}\text { - OS : SymbianOS v3 } \\
\text { - Perangkat : Nokia } \\
\text { - Layar : } 360 \text { x640 }\end{array}$ & Berhasil \\
\hline 8. & iPhone 4/4s & $\begin{array}{l}\text { - OS : iOS versi } 5 \\
\text { - Manufacture : Apple } \\
\text { - Layar : } 640 \text { x } 960\end{array}$ & Berhasil \\
\hline & iPhone 5 & $\begin{array}{l}\text { - OS : iOS versi } 6 \\
\text { - Perangkat: Apple } \\
\text { - Layar : } 640 \times 1136\end{array}$ & Berhasil \\
\hline
\end{tabular}

3. Implementasi Antar Muka Perangkat Lunak

Adapun implementasi tampilan antarmuka Aplikasi Simatik berbasis Multi Platform adalah sebagai berikut.

(A). Antar Muka Login Administrator
Antarmuka halaman login merupakan antarmuka yang digunakan Admin dan Operator untuk masuk ke dalam aplikasi berbasis web. Admin dan Operator akan diminta mengisi Username dan Password untuk login. 


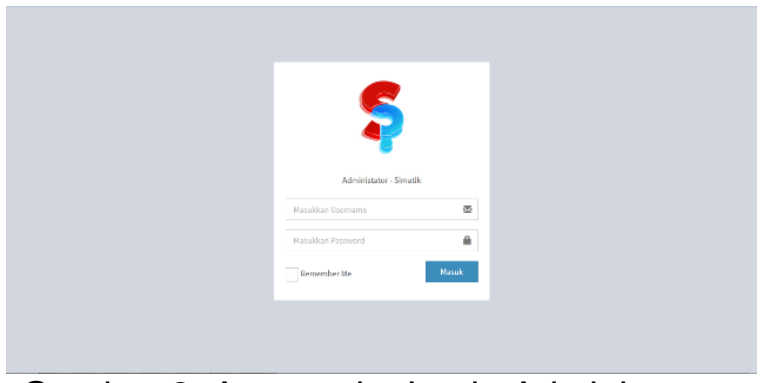

Gambar 2. Antarmuka Login Administrator

(B). Antar Muka Halaman Dashboard Merupakan tampilan antarmuka dashboard yang merupakan halaman utama yang akan muncul jika pengguna berhasil login sebagai admin maupun operator. Pada antar muka halaman Dashboard berisi informasi status data yang masuk kedalam sistem.

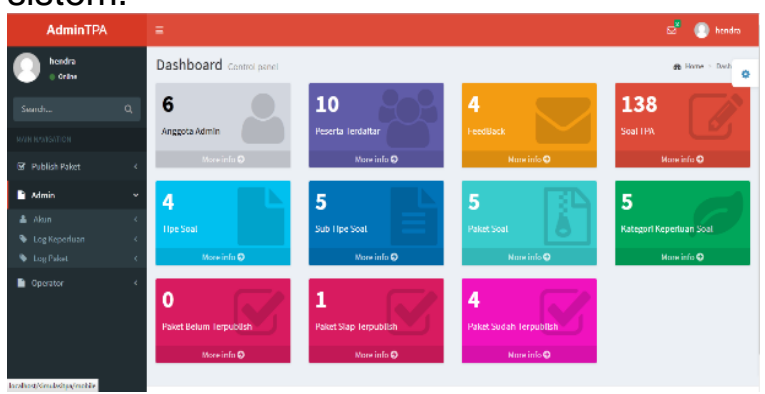

Gambar 3. Antarmuka Dashboard Administrator

\section{(C). Antar Muka Cek Soal Publish}

Tampilan antar muka cek soal publish digunakan untuk melakukan pengecekan soal-soal sebelum paket di publish. Bila tidak ada kesalahan berarti pada soal maka paket bisa di Publish. Pada tampilan ini terdapat tombol "Publish" untuk mempublish paket soal dan daftar soal-soal yang akan masuk ke dalam paket yang akan di publish. Pada daftar soal, Operator atau Admin dapat melihat detail soal dan detail penanggung jawab.

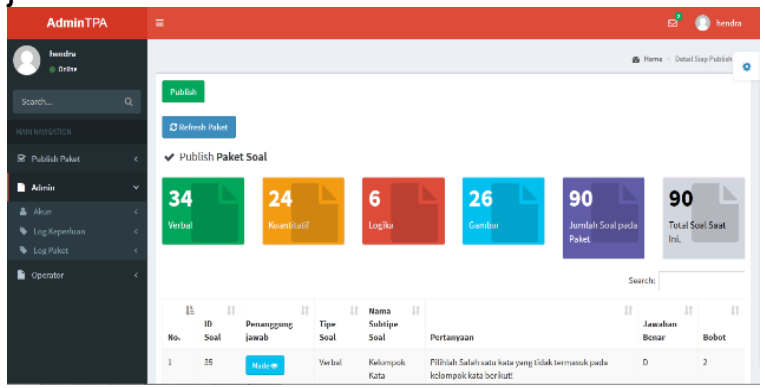

Gambar 4. Antarmuka Cek Soal Publish
(D). Antar Muka Splash Screen dan Awal

Antarmuka Splash Screen akan muncul sesaat setelah aplikasi dibuka dan halaman awal sesaat setelah splash screen. Pada antar muka Splash Screen menampilkan logo dan pada halaman Tampilan Awal menampilkan kelebihan aplikasi Simatik berbasis Multi Platform
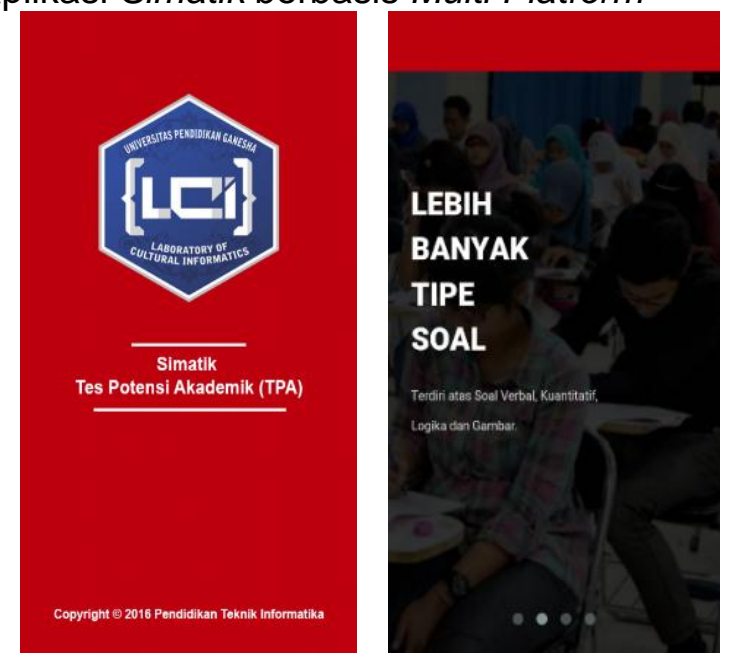

Gambar 5. Antarmuka Splash Screen (Kiri) dan Halaman Awal Aplikasi (Kanan)

(E). Antar Muka Daftar dan Login

Pada halaman daftar, pengguna harus memasukkan email beserta data pribadi. Untuk bisa login ke aplikasi, pengguna diharuskan untuk memverifikasi akun melalui email yang didaftarkan. Setelah email terverifikasi, maka pengguna dapat login dengan memasukkan email dan password terlihat pada gambar 8 .

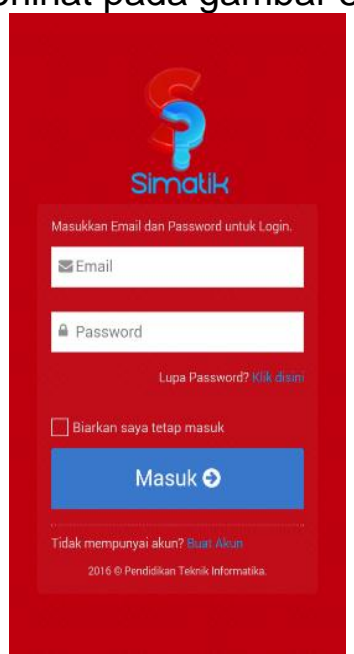

Gambar 6. Antarmuka Halaman Daftar (Kiri) dan Halaman Login (Kanan) 
(F). Antar Muka Dashboard dan Sidebar
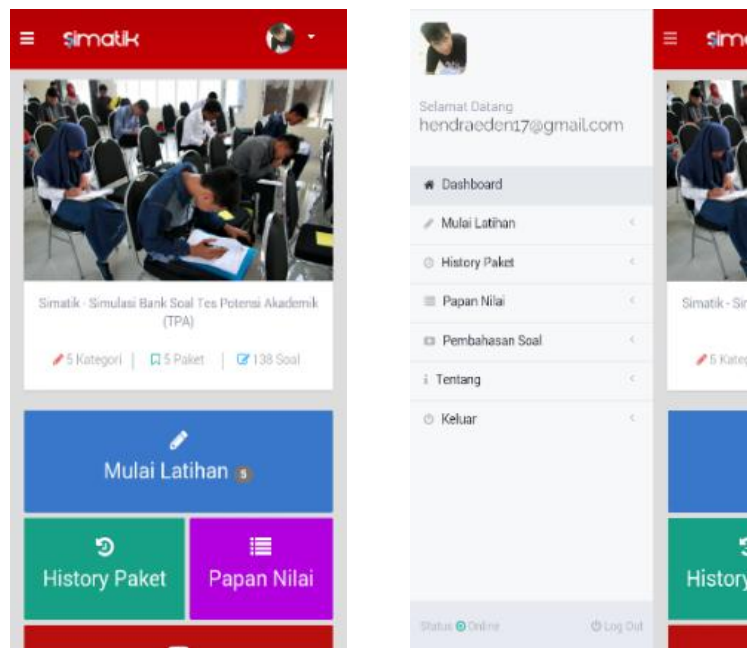

Gambar 7. Antarmuka Dashboard (Kiri) dan Sidebar (Kanan)

(G). Antar Muka Latihan Soal dan Skor

Antarmuka halaman latihan

merupakan halaman yang digunakan Peserta untuk melakukan latihan soal-soal terkait TPA. Pada halaman ini terdapat tampilan timer, pertanyaan, radio button untuk memilih jawaban yang dianggap benar dan navigasi untuk lanjut ke soal berikutnya.

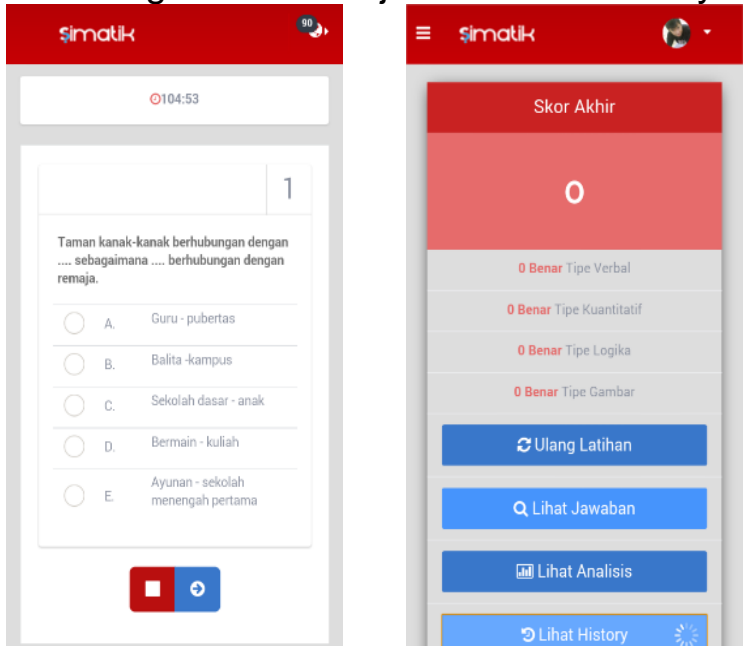

Gambar 8. Antarmuka Latihan Soal (Kiri) dan Halaman Skor (Kanan)

(H). Antar Muka Papan Nilai dan Pembahasan

Antarmuka halaman papan nilai merupakan halaman yang digunakan Peserta untuk melihat daftar nilai tertinggi berdasarkan tipe soal dari masing-masing peserta.
Sedangkan antar muka pembahasan soal menampilkan pembahasan dalam bentuk video animasi.

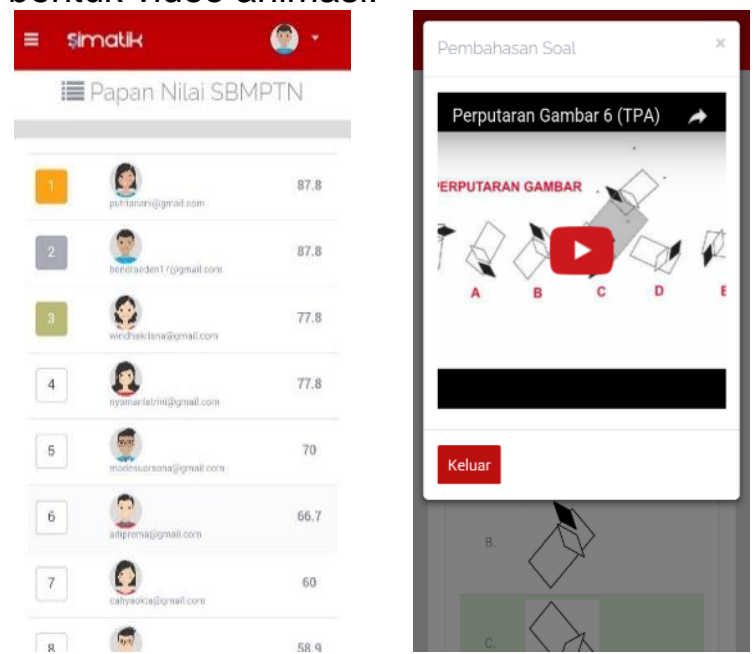

Gambar 9. Antarmuka Papan Nilai (Kiri) dan Daftar Pembahasan Soal (Kanan)

(I). Antar Muka Kelola Soal

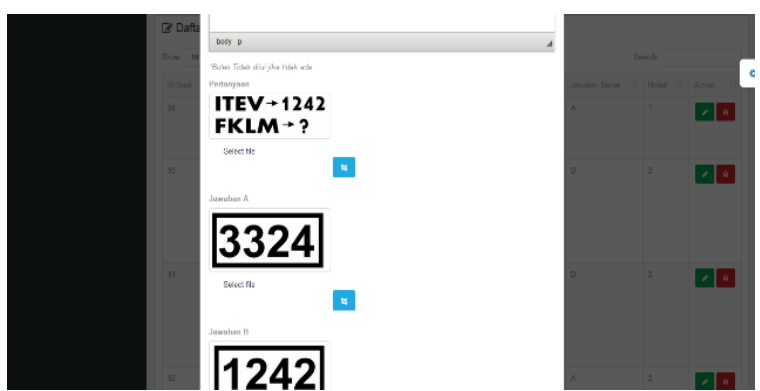

Gambar 10. Antarmuka Kelola Soal

\section{B. Evaluasi dan Pembahasan Perangkat Lunak}

Secara global pelaksanaan pengujian perangkat lunak baik pada saat melakukan Uji Ahli Isi, Blackbox testing, Whitebox testing, Uji Usability dan Uji Respon Pengguna berlangsung dengan lancar.

Pada pengujian Ahli Isi mendapatkan hasil persentase sebesar $82,9 \%$ dengan kategori baik dan revisi sedikit. Hasil pengujian Ahli Isi ini dikatakan baik karena masih terdapat beberapa kesalahan berupa ejaan dan tata cara penulisan kata serta komposisi soal yang masih belum diurut berdasarkan tipe soal. Selain itu juga bila dibandingkan dengan teori yang digunakan, butir pengujian dan fitur yang terdapat pada Aplikasi Simatik Berbasis Multi Platform sudah sesuai baik itu dari segi jumlah soal 
dan waktu yang didapat dari perbandingan dengan buku-buku penyedia latihan soal dan aplikasi-aplikasi terkait Tes Potensi Akademik (TPA) lain, komposisi soal yang terdiri dari tipe soal Verbal, Kuantitatif, Logika dan Gambar serta penggunaan teori aplikasi Mobile untuk memudahkan penggunaan aplikasi disegala tempat dan waktu.

Pada uji blackbox testing, mulai dari saat pertama kali aplikasi dijalankan pada perangkat Mobile untuk aplikasi Simatik dan Web untuk halaman administrator sampai dengan selesai dan keluar, aplikasi Simatik berbasis Multi Platform berfungsi dengan baik. Hasil pengujian blackbox testing dikatakan baik karena semua fitur seperti daftar aplikasi, login ke aplikasi, kelola soal, kelola paket soal, latihn soal, perolehan skor dan lain sebagainya pada aplikasi ditampilkan sesuai dengan yang diharapkan. , secara keseluruhan aplikasi Simatik berbasis Multi Platform sudah dapat berjalan pada berbagai perangkat Mobile (Multi Platform).

Pengujian white box dilakukan terhadap source code dengan tujuan menguji alur proses dan logika yang ada. Dari hasil pengujian tersebut dapat disimpulkan bahwa semua fungsi code HTML 5 dan PHP pada teori yang digunakan dan diimplementasikan pada aplikasi Simatik berbasis Multi Platform dapat berjalan dengan baik dan benar.

Pada pengujian Usability mendapatkan hasil presentase sebesar 95,6 $\%$ dengan kategori sangat baik. Persentase tersebut didapat dari total rata-rata persentase Learnability, Efficiency, Memorability, Error dan Satisfaction.. Pada kelima pengujian tersebut mendapatkan hasil dengan kategori sangat baik. Dengan hasil pengujian usability yang dalam kategori sangat baik berarti aplikasi sudah dapat berjalan dan digunakan sesuai dengan fungsi dari aplikasi yang diharapkan. Namun, masih terdapat beberapa perbedaan ukuran layout dari beberapa perangkat mobile yang digunakan untuk melakukan uji coba. Hal ini terjadi karena layout pada aplikasi menyesuaikan dengan ukuran layar dari masing masing perangkat mobile.
Berdasarkan uji respon pengguna, data rata rata respon pengguna memberikan hasil persentase sebesar $100 \%$ dengan kategori sangat baik. Hasil pengujian uji respon pengguna dikatakan baik berdasarkan penilaian pada masing-masing butir yang diujikan pada uji respon pengguna yang bernilai positif. Sehingga dapat disimpulkan bahwa aplikasi Simatik berbasis Multi Platform ini, layak digunakan dalam latihan soal-soal yang terkait dengan Tes Potensi Akademik (TPA).

\section{SIMPULAN}

1. Aplikasi Simatik berbasis Multi Platform dirancang dengan menggunakan pemodelan fungsional berupa UML, dan menggunakan arsitektur client - server dalam hal pertukaran data dan informasi serta di implementasikan menggunakan bahasa pemrograman HTML 5 dengan framework Phonegap, sehingga dapat digunakan di berbagai platform perangkat mobile.

2. Pengujian Aplikasi Simatik berbasis Multi Platform dilakukan dengan beberapa cara dan mendapatkan hasil sebagai berikut. Yang pertama yaitu Pengujian Uji Ahli Isi yang mendapatkan hasil persentase sebesar 82,9 \% dengan kategori baik dan revisi sedikit. Kedua adalah pengujian blackbox yang mendapatkan hasil semua fitur pada aplikasi ditampilkan sesuai dengan yang diharapkan. Ketiga adalah pengujian dengan menggunakan whitebox testing dimana semua source code serta logika - logika yang ada berjalan dengan baik dan tidak ada error yang terjadi. Hasil uji yang keempat yaitu uji usability yang menunjukkan bahwa aplikasi sudah dapat berjalan sesuai dengan fungsi yang diharapkan dengan presentase hasil uji sebesar 95,6 \% dan kategori sangat baik dimana dengan presentase masing masing kategori yaitu Learnability $96 \%$, Eficiency 95,2 \%, Memorability 94,8 \%, Error 94,8 \%, dan Satisfaction 96,6\%. Untuk hasil uji responden, aplikasi Simatik berbasis Multi Platform mendapatkan presentase hasil uji sebesar $100 \%$ dengan kategori sangat baik. Secara keseluruhan, hasil uji sudah berjalan dengan lancar dan 
dapat disimpulkan aplikasi Simatik berbasis Multi Platform layak digunakan dalam latihan soal-soal yang terkait dengan Tes Potensi Akademik (TPA).

\section{SARAN}

1. Pada pengujian Uji Ahli Isi masih mendapatkan hasil pengujian Baik dengan Revisi yang dalam pengembangan selanjutnya diharapkan agar isi yang terkandung dalam aplikasi lebih diperhatikan untuk mendapatkan hasil yang maksimal.

2. Implementasi perangkat lunak aplikasi pada perangkat Multi Platform hanya beberapa saja dapat dilakukan karena terkendala waktu dan perangkat Multi Platform yang minim. Diharapkan pada pengembangan selanjutnya Implementasi perangkat lunak aplikasi tidak hanya melalui Emulator, tetapi dapat di implementasikan pada semua jenis sistem operasi mobile.

3. Dalam pengembangan selanjutnya, diharapkan aplikasi tidak hanya bisa berjalan secara online, melainkan sudah dapat berjalan secara offline ehingga aplikasi masih dapat digunakan apabila pengguna tidak dapat terkoneksi ke jaringan internet.

4. Aplikasi Simatik berbasis Multi Platform masih berupa aplikasi semi mobile atau webview sehingga respon setiap pengguna membuka suatu halaman aplikasi masih terlalu lamban. Diharapkan kedepannya pengembangan aplikasi Simatik berbasis Multi Platform dibuat secara native menggunakan Software Editor Khusus (Eclipse, Android Studio) untuk pengembangan aplikasi Phonegap.

\section{DAFTAR PUSTAKA}

Chumairoh, M. S. (2014). Perancang Bangun Aplikasi Mobile Pada Platform Android Berbasis Html5 Studi Kasus Layanan Informasi Website Unipdu Jombang. Jurnal IImiah Edutic, Vol.1, No.1, 1-6.

Developers Android. (2015). Diambil kembali dari http://developer.android.com: http://developer.android.com/about/ve rsions/lollipop.html

Dewantara, A., \& Kumala, C. (2010). Kupas Tuntas Tes Potensi Akademik Masuk Perguruan Tinggi. Yogyakarta: Pustaka Widyatama.

Heizer, J., \& Render, B. (2005). Operations Management. Jakarta: Salemba Empat

Ibrahim, R. N. (2013). Pengembangan Aplikasi Belajar Menulis Alfabet Dan Angka Untuk Perangkat Mobile Berbasis Android Dan los Menggunakan Framework Cocos2. Jurnal Computech \& Bisnis, Vol. 7, No. $1,1-12$

Kertiasih, N. K. (2011). Pengembangan ELearning MPK Bahasa Indonesia Menggunakan Model ADDIE untuk Perkulihan di Universitas Pendidikan Ganesha. Tesis (tidak diterbitkan). Program Studi Teknologi Pembelajaran, Pasca Sarjana Undiksha.

Nasution, \& Baihaqi. (2007). Simulasi Bisnis. Yogyakarta: Andi.

tespotensiakademik. (2015). Diambil kembali dari www.tespotensiakademik.com: http://www.tespotensiakademik.com/a pa-yang-dimaksud-dengan-tpa.php.

Yudistira, Y. (2011). Membuat Aplikasi iPhone, Android \& Blackberry Itu Gampang. Jakarta Selatan: Mediakit 